This item is the archived peer-reviewed author-version of:

The powers of national regulatory authorities as agents of EU law

\title{
Reference:
}

De Somer Stéphanie.- The pow ers of national regulatory authorities as agents of EU law

ERA-forum: scripta iuris europaei. - ISSN 1727-6926 - 18:4(2018), p. 581-595

Full text (Publisher's DOI): https://doi.org/10.1007/S12027-017-0487-Y

To cite this reference: $h$ ttp://hdl.handle.net/10067/1522690151162165141 


\section{The Powers of National Regulatory Authorities as Agents of EU law}

Stéphanie De Somer

Postdoctoral fellow FWO Flanders, University of Antwerp

stephanie.desomer@uantwerpen.be

\section{Abstract}

Over the past few decades, National Regulatory Authorities have acquired a central role in the implementation of EU law. NRAs are established by the Member States, implying that they are part of the national administrative organization chart. Their creation, however, is compulsory under EU law. Today's NRAs derive most of their competences from EU legislation, even if the formal legal basis of their tasks and powers is typically the national legislation that implements the EU directives. Focusing on NRAs in the field of network regulation, which are characterized by the far-reaching requirements of (political) independence that EU law imposes, this paper maps this trend of 'empowering' NRAs and some of the challenges on the level of accountability that go hand in hand with it.

Keywords

National Regulatory Authorities - Network Industries - Powers - Accountability - Judicial Review

\section{Introduction}

For the purpose of this article, National Regulatory Authorities (NRAs) are defined as administrative authorities, established at Member State level, that are separate from the central state administration and that are entrusted with specific regulatory or supervisory ${ }^{1}$ missions that involve the implementation of EU legislation. NRAs operate in various regulatory domains, that range from media regulation to the safety of nuclear installations or the investigation of maritime accidents. Naturally, the respective missions and powers of all these bodies differ considerably.

NRAs are not necessarily IRAs, i.e. Independent Regulatory Authorities. What defines NRAs is their 'separateness'. They are highly specialized bodies with a narrow mandate, who develop a specific expertise in a well-defined domain, allowing them to benefit from economies of scale, since they deal with high numbers of similar cases. ${ }^{2}$ IRAs on the other hand are NRAs that enjoy a specific degree of independence, both from the regulated or supervised parties and from other public bodies, especially the political executive. In some areas, EU legislation explicitly requires independence. NRAs operating in the network industries are the best known examples of this trend and will be central to this article. ${ }^{3}$ In the field of electronic communications, the CJEU has ruled on various occasions that, although Member States enjoy institutional autonomy as regards the organization and the structuring of NRAs, that autonomy may be exercised only in full compliance with the objectives and obligations laid down in the directives. ${ }^{4}$ Hence, the principle of institutional autonomy does not have any constitutional value: the EU legislature can limit Member States' autonomy in this respect by laying down provisions of an institutional nature.

In the regulatory domains of energy (electricity and gas) and railway transport, the relevant EU legislation ${ }^{5}$ currently contains the most straightforward obligations on the political independence of NRAs, which is the most controversial aspect of the twofold independence requirement. ${ }^{6}$ In a more indirect way, such an obligation of

\footnotetext{
${ }^{1}$ Some legislation uses the term 'national supervisory authority': see e.g. art. 4 of Regulation 549/2004 of the European Parliament and of the Council of 10 March 2004 laying down the framework for the creation of a single European sky (the framework regulation), OJ L 96/1.

${ }^{2}$ Nicolaïdes [15], p. 29.

${ }^{3}$ Another type of national supervisory authorities subject to such independence requirements are the data protection authorities. See art. 5254 Regulation 2016/679/EU of the European Parliament and of the Council of 27 April 2016 on the protection of natural persons with regard to the processing of personal data and on the free movement of such data, and repealing Directive 95/46/EC (General Data Protection Regulation) [2016] OJ L 119/1. These provisions were to an important extent inspired by the case law of the CJEU on the notion of 'complete independence' that was anchored in art. 28 of the Data Protection Directive. See Case C-518/07 Commission/Germany, EU:C:2010:125; Case C-614/10 Commission/Austria, EU:C:2012:631; Case C-288/12 Commission/Hungary, EU:C:2014:237.

${ }^{4}$ Case C-82/07 Comisión del Mercado de las Telecomunicaciones, EU:C:2008:143, para 24; Case C-389/08 Base NV and Others v Ministerraad [2010] ECR I-9073; Case C-85/14 KPN BV, EU:C:2015:610.

${ }^{5}$ References to EU legislation should be read as references to the consolidated text, as amended by later legislation.

${ }^{6}$ Art. 35 Directive 2009/72/EC of the European Parliament and of the Council of 13 July 2009 concerning common rules for the internal market in electricity and repealing Directive 2003/54/EC [2009] OJ L 211/5; art. 39 of Directive 2009/73/EC of the European Parliament and of the Council of 13 July 2009 concerning common rules for the internal market in natural gas and repealing Directive 2003/55/EC [2009] OJ
} 
political independence also follows from the (consolidated version of the) Framework Directive in the field of electronic communications. ${ }^{7}$ For postal services, the legislative framework currently only anchors an obligation of independence vis-à-vis the regulated parties. ${ }^{8}$ A European Commission proposal to amend the Audiovisual Media Services Directive contains provisions on the independence of media regulators. ${ }^{9}$

EU law, however, is not only becoming more specific when it comes to the institutional design of NRAs. It also increasingly specifies the competences that NRAs should be invested with. Hence, EU law is a direct source of missions and powers for specific bodies within the domestic administrative apparatus. The following title briefly maps this influence. The article then turns to the more normative question of accountability.

\section{The missions and powers of NRAs operating in the network industries: features}

\subsection{NRAs are typically single-purpose bodies}

Even though NRAs are defined by the specificity of their mandate, EU legislation sometimes explicitly allows for the creation of multi-purpose bodies. An example is found in the latest directive on the liberalization of the railway sector, which allows the competent regulatory authority to merge with the national competition authority, as long as the joint body fulfils the independence requirements laid down in the directive. ${ }^{10}$ Recently, the ECJ has ruled that the Framework Directive (in the area of electronic communications) does not preclude national legislation which entails the merger of a national regulatory authority with other national regulatory authorities in order to create a multisectional regulatory body. In performing its tasks, however, the body has to meet the requirements of competence, independence, impartiality and transparency laid down in the Framework Directive and an effective right of appeal to a body independent of the parties involved has to be available against its decisions. ${ }^{11}$ In the Netherlands, for instance, a unified market supervisory authority was established in $2013 .{ }^{12}$ In France, the regulatory body competent for the markets of electronic communications and postal services is the same ${ }^{13}$, as is the case in Belgium ${ }^{14}$.

\subsection{Missions versus powers}

There is great legislative variety in the way in which the missions and powers of NRAs are defined and delineated. What seems to be constant in the network industries, is that the provisions become more detailed or sophisticated with every new generation of directives.

The directives do not always make a clear distinction between the missions that NRAs should be made responsible for and the powers that Member States should invest them with. The concept of 'missions' refers to the substantive scope of NRAs' competences, whereas 'powers' are the formal instruments of decision-making and especially the coercive powers that they possess. In the field of railway transport, for instance, one article in the Directive is dedicated to the 'functions' of NRAs and covers both their missions and powers. ${ }^{15}$ In the field of regulation of the energy markets, on the other hand, the directive more or less clearly upholds the distinction between objectives, 'duties' (i.e. missions) and powers of the NRA. ${ }^{16}$

\subsection{Broad discretionary powers}

It has been argued that independent agencies 'are an independent locus of policy 'creation' not 'administration" 17 . NRAs indeed exercise their powers with considerable discretion. There is a direct and linear relationship between

L 211/94; art. 55 Directive 2012/34/EU of the European Parliament and of the Council of 21 November 2012 establishing a single European railway area [2012] OJ L 343/32.

${ }^{7}$ Art. 3, para 3a Directive 2002/21/EC of the European Parliament and of the Council of 7 March 2002 on a common regulatory framework for electronic communications networks and services (Framework Directive) [2002] OJ L 108/33.

${ }^{8}$ See art. 22 of Directive 97/67/EC of the European Parliament and of the Council of 15 December 1997 on common rules for the development of the internal market of Community postal services and the improvement of quality of service [1998] OJ L 15/14.

${ }_{9}^{9}$ Proposal for a Directive of the European Parliament and of the Council amending Directive 2010/13/EU on the coordination of certain provisions laid down by law, regulation or administrative action in Member States concerning the provision of audiovisual media services in view of changing market realities (COM/2016/0287).

${ }^{10}$ Art. 55(2) of Directive 2012/34/EU.

${ }^{11}$ Case C-424/15 Xabier Ormaetxea Garai en Bernardo Lorenzo Almendros, EU:C:2016:780.

${ }^{12}$ Https://www.acm.nl/en/.

${ }^{13}$ Https://www.arcep. $f r /$

${ }^{14}$ Http://www.bipt.belen.

${ }^{15}$ Art. 56 of Directive 2012/34/EU.

${ }^{16}$ Art. 36 and 37 of Directive 2009/72/EC; articles 40 and 41 of Directive 2009/73/EC.

${ }^{17}$ Halberstam [6], p. 189. 
the degree of (political) independence that these authorities enjoy and the nature and impact of the powers that they are invested with. Others have noted that the $\mathrm{CJEU}^{18}$ tends to interpret NRAs' competences or missions in the network industries in a broad, rather than a narrow sense. ${ }^{19}$ Regularly, however, there is a discrepancy between the intention of the EU legislature regarding the powers that NRAs should have and the actual implementation at the national level. National legislatures are not always keen to invest separate, let alone independent, authorities with broad decision-making powers. In Belgium, for instance, the federal energy regulatory authority turned to the Constitutional Court in 2013 because it believed that the legislature had not correctly transposed the third energy liberalization package into national law. It more precisely claimed that the statute did not fully guarantee that it could exercise all the powers that EU law reserved for the regulatory body with full independence. The Constitutional Court indeed annulled some of the statutory provisions that were challenged.$^{20}$ In another judgment, pronounced in 2016, the Court annulled a provision of a Walloon decree that limited the discretionary power of the competent regulatory authority (the Walloon regulatory authority for energy) to decide on a tariff methodology. Again, it was the affected regulatory body itself that initiated the proceedings before the Court. ${ }^{21}$ There are many other domestic examples of what other authors have labelled the 'fragile position' of NRAs in domestic law $^{22}$, i.e. attempts by national legislatures or governments to curtail the powers of NRAs in the network industries or to limit their independence. These conservative reflexes at the domestic level do not come as a surprise. Typically, the combination of broad discretionary powers with a lack of political oversight is hard to reconcile with national constitutional principles governing administrative organization. ${ }^{23}$

\subsection{A combination of advisory powers, coercive powers and investigatory powers}

Most NRAs possess three types of powers. Firstly, they give advice to central state institutions, being legislatures and governments. Secondly, they possess coercive powers: i.e. binding unilateral decision making powers that create rights for individuals or impose obligations or burdens on them. Thirdly, they have a number of supportive powers, i.e. powers that are accessory to their coercive decision-making powers. Examples of the latter are powers to require information, powers of investigation and auditing powers. In the area of railway transport, for instance, the regulatory body has to be invested with the power to request relevant information from the infrastructure manager, applicants and any third party involved within the Member State concerned. The NRA should be able to enforce such requests with appropriate penalties, including fines. ${ }^{24}$ In the area of regulation of the electricity markets, the NRA should enjoy the power to carry out inspections, including unannounced ones, on the premises of the vertically integrated undertaking and the transmission system operator. ${ }^{25}$

\subsection{A combination of normative, adjudicatory and enforcement powers}

Many NRAs combine aspects of the three traditional functions of the state. Firstly, they have normative powers, meaning that they can issue rules that are applicable to all or to a predefined group of (regulated) parties. Examples are found, for instance, in the area of the regulation of postal services, where the NRA can to some extent derogate from or give a different content to the scope of the universal service obligation (e.g. increase the weight limit to any weight not exceeding 20 kilograms or lay down specific arrangements for the door-to-door delivery) ${ }^{26} \mathrm{NRAs}$ in charge of the regulation of the energy markets should have the power to fix or approve, in accordance with transparent criteria, transmission or distribution tariffs or their methodologies. ${ }^{27}$ They also set or approve standards and requirements for quality of service and supply or contribute thereto with other competent authorities. ${ }^{28}$

\footnotetext{
${ }^{18}$ See e.g. Case C-424/07 Commission v Germany, EU:C:2009:749.

${ }^{19}$ Lavrijssen and Ottow [12], p. 95; Aelen [1], p. 249-254; Ziller [25], p. 901-906.

${ }^{20}$ Belgian Constitutional Court 7 August 2013, $\mathrm{n}^{\circ} 117 / 2013$.

${ }^{21}$ Belgian Constitutional Court 25 May 2016, $\mathrm{n}^{\circ} 71 / 2016$.

${ }^{22}$ Lavrijssen and Ottow [11], p. 431; Ottow [17], p. $143 \mathrm{ff.}$

${ }^{23}$ De Somer [4], p. 223-250.

${ }^{24}$ Art. 56(8) of Directive 2012/34/EU.

${ }^{25}$ Art. 37(5)(g) of Directive /EC.

${ }^{26}$ Art. 3(3) of Directive 97/67/EC.

${ }^{27}$ On the extent of this power, see Commission Staff Working Paper 22 January 2010, Interpretative Note on Directive 2009/72/EC concerning common rules for the internal market in electricity and Directive 2009/73/EC concerning common rules for the internal market in natural gas - The Regulatory Authorities, http://ec.europa.eu/energy/gas electricity/interpretative notes/doc

/implementation_notes/2010_01_21_the_regulatory_authorities.pdf, p. 13-14.

${ }^{28}$ Art. 37(1) (a) and (h) of Directive 2009/72/EC; article 41(1) (a) and (h) of Directive 2009/73.
} 
Secondly, NRAs have powers to take decisions with an individual scope. An example, again in the field of energy regulation, is the power to approve commercial and financial agreements between vertically integrated undertakings and transmission system operators. ${ }^{29}$

Finally, NRAs have powers of enforcement, i.e. quasi-judicial powers. Some NRAs are invested with powers to issue binding decisions in order to resolve disputes. Examples are found in the areas of electronic communications $^{30}$, energy ${ }^{31}$ and railway transport ${ }^{32}$. NRAs may also have powers to impose penalties after complaints or even ex officio. In the area of railway transport, the directive requires the competent regulatory body to be able to enforce its decisions with the appropriate penalties, including fines. ${ }^{33}$ Electricity regulators should be invested with the power to impose effective, proportionate and dissuasive penalties on electricity undertakings not complying with their obligations. However, in this case, the directive provides an alternative: the national legislature can also decide to give the NRA the mere possibility of proposing to impose such penalties to a competent court. ${ }^{34} \mathrm{An}$ interpretative note issued by the European Commission clarifies that the latter possibility was included in the directives because the constitutional system of some Member States does not permit that independent bodies would be invested with sanctioning powers. ${ }^{35}$

The combination of such a variety of powers in the hands of a single administrative body as such may also not be obvious in the light of national constitutional approaches to the separation of powers doctrine. ${ }^{36}$ However, nothing in the directives seems to prevent Member States from creating subsections within regulatory bodies in order to ensure that different individuals are in charge of these different functions. In France, for instance, the Conseil Constitutionnel verifies whether the institutional design of regulatory bodies with sanctioning powers guarantees a functional separation between the stages of prosecution and adjudication. ${ }^{37}$

\subsection{Powers of NRAs versus powers of NCAs}

Economic regulation in EU law consists of two components: general competition law (enforced, at the national level, by the NCAs or National Competition Authorities) on the one hand and sector-specific regulation (enforced by NRAs) on the other hand..$^{38}$ According to most literature, there is a preference for sector-specific regulation if and as long as specific ex-ante obligations of preventive nature are necessary to reduce the risk of market failures. 'In later stages and as competition intensifies, sector-specific rules are gradually replaced by general competition rules. ${ }^{39}$ Roughly, regulatory authorities are responsible for ex ante regulation in recently liberalized markets with a history of monopolies and high risks for the public interest(s) at stake. General competition authorities, on the other hand, act ex post facto and the scope of their supervision extends to all markets that are subject to competition. ${ }^{40}$ The powers that are typically granted to each type of authority correspond to these different roles: whereas regulators mainly operate through powers of rule making and adjudication (e.g. licensing), general competition authorities' remit tends to focus more on dispute resolution and sanctioning, implying that their decisions are often quasi-judicial in nature. The picture, however, is not black and white. As we have seen, NRAs increasingly possess such quasi-judicial powers as well. Competition authorities, on the other hand, also have $e x$ ante powers (notably with respect to concentration control).

We have seen that EU legislation itself determines which missions and powers NRAs in the network industries have to be invested with (as a minimum ${ }^{41}$ ). The situation for NCAs is by no means comparable: there is a great

\footnotetext{
${ }^{29}$ Art. 37(5)(e) of Directive 2009/72/EC; art. 41(5)(e) of Directive 2009/73/EC.

${ }^{30}$ Art. 20 of Directive 2002/21/EC.

${ }^{31}$ Art. 37(5)(c) of Directive 2009/72/EC; art. 41(5)(c) of Directive 2009/73/EC.

${ }^{32}$ Art. 56(1) of Directive 2012/34/EU.

${ }_{33}$ Art. 56(9) of Directive 2012/34/EU.

${ }^{34}$ Art. 37(4)(d) of Directive 2009/72/EC. A parallel provision is found in the Gas Directive: article 41(4)(d) of Directive 2009/73/EC

${ }^{35}$ See Commission Staff Working Paper 22 January 2010, Interpretative Note on Directive 2009/72/EC concerning common rules for the internal market in electricity and Directive 2009/73/EC concerning common rules for the internal market in natural gas - The Regulatory Authorities, http://ec.europa.eu/energy/gas_electricity/interpretative_notes/doc address the relationship between NRAs and NCA, mostly by imposing duties of mutual information and cooperation: see e.g. article 22 Directive 97/67/EC; article 3(5) of Directive 2002/21/EC; article 37(1) (k) and (o) and article 37(4)(b) of Directive 2009/72/EC.

${ }^{41}$ See Commission Staff Working Paper 22 January 2010, Interpretative Note on Directive 2009/72/EC concerning common rules for the internal market in electricity and Directive 2009/73/EC concerning common rules for the internal market in natural gas - The Regulatory Authorities, 
variety among Member States when it comes to the powers that they invest their NCAs with. For that reason, the European Commission recently launched a proposal for a directive that aims to reinforce the position of NCAs. The proposal amongst other things anchors the principle of independence for NCAs (in much the same way as the liberalization directives do for NRAs) and specifies the power that these bodies should possess. ${ }^{42}$

\section{Questions of accountability}

Due to their independence, IRAs lack the democratic legitimacy that other administrative authorities derive from their connection to the political executive. They are not subject to traditional forms of political oversight. ${ }^{43}$ Other accountability mechanisms apply to them, however. ${ }^{44}$ As the provisions in EU legislation on the precise missions and powers that NRAs should possess become ever more detailed, so does the attention for their accountability. This is mainly true for two types of accountability: accountability through procedural guarantees and legal accountability. ${ }^{45} \mathrm{We}$ also briefly address two accountability mechanisms that are located at the supranational level: network accountability and accountability to the European Commission.

\subsection{Procedural accountability}

Procedural accountability takes place via mechanisms that make regulators answer to regulated parties and stakeholders during the administrative process. Ideally, these mechanisms can even lead to a dialogue. Participatory mechanisms are central to this type of accountability. EU legislation now often enshrines requirements or duties for NRAs to consult stakeholders in general or specific regulated parties for particular decisions. ${ }^{46}$ For these mechanisms to be effective in practice, it is key that NRAS offer sufficient levels of transparency. Therefore, EU legislation often explicitly requires NRAs to publish their decisions (with respect for the confidentiality of commercially sensitive information). ${ }^{47}$ Participation can only lead to accountability, however, if the NRA also explains how it has used the input that it received, to what extent it has implemented suggestions etc. Many NRAs have strongly invested in the design of their consultation procedures and experiment with different types of participation. The Dutch unified market supervisory authority ACM, for instance, organizes consultations regarding the policy rules that it issues. Sometimes, stakeholders are invited to submit comments on the regulator's website. In other cases, however, the ACM has been known to organize roundtables that allow for a genuine debate. ${ }^{48}$

NRAs are furthermore subject to the general principles of good administration, such as the right to be heard or to have a case handled within a reasonable time. Article 41 of the Charter of Fundamental Rights of the European Union has given good administration the status of a fundamental right. Contrary to the other fundamental rights in the Charter ${ }^{49}$, the right to good administration only applies to the institutions and bodies of the Union, but not to the Member States when they implement or act within the scope of EU law. ${ }^{50}$ NRAs may be 'agents of EU law"; from an institutional viewpoint, they are embedded in the Member States' administrative systems. The principles of good administration, however, have been developed by the CJEU as part of the EU's unwritten law. They remain relevant for the Member States and their administrative bodies, even if the scope of the codified right to good administration does not include them. ${ }^{51}$ The body of principles of good administration recognized by the CJEU (or in the European Code of Good Administrative Behaviour) is, moreover, more extensive than the list that figures in article 41 of the Charter, which, amongst others, does not mention the proportionality principle, the principle of legal certainty or the principle of due care.

/implementation_notes/2010_01_21_the_regulatory_authorities.pdf, p. 12 and 17: Member States may give the NRA additional duties and powers to those specified in the directives. There seems to be no reason why this would not also be the case in the other network industries.

${ }^{42}$ Proposal for a Directive of the European Parliament and of the Council to empower the competition authorities of the Member States to be more effective enforcers and to ensure the proper functioning of the internal market (COM/2017/0063).

${ }^{43}$ They typically do remain subject to general forms of parliamentary oversight, meaning, for instance, that they submit annual reports to their national parliaments.

${ }^{44}$ See De Somer [4], p. 251-267.

${ }^{45}$ Another important aspect is NRAs' financial accountability. Member States can make their NRAs' subject to general legislation concerning public finances in general and to specific provisions regarding the control and rationalization of expenses of government services: Case C240/15 Autorità per le Garanzie nelle Comunicazioni, EU:C:2016:608.

${ }^{46}$ E.g. art. 6 of Directive 2002/21/EC; art. 37(2) of Directive 2009/72/EC; art. 41(2) of Directive 2009/73/EC; art. 56(7) of Directive 2012/34/EU.

${ }^{47}$ E.g. art. 37(16) of Directive 2009/72/EC; art. 41(16) of Directive 2009/73/EC; art. 56(11) of Directive 2012/34/EU.

${ }^{48}$ Vegter and Maandag [24], p. 214.

${ }^{49}$ See art. 51.

${ }^{50}$ This follows from art. 41(1) of the Charter. See also Case C-482/10 Teresa Cicala, EU:C:2011:868, para 28; Kańska [9], p. 309.

${ }^{51}$ Kristjánsdóttir [10], p. 248-252; Hofmann and Mihaescu [8], p. 73-101. 
Because NRAs fall under the scope of both national and EU principles of good administration, meaning that the highest level of protection for individuals will prevail, their decision-making process often reaches higher degrees of procedural fairness than that of central administrations. An illustration is found in the case law of the Brussels Court of Appeal in a case against the Belgian federal energy regulatory authority. The case concerned another very important guarantee of procedural accountability: the duty to give reasons. The NRA argued that its tariff decision did not have to contain reasons, since the Belgian statute anchoring the duty to give reasons for administrative acts only applies to decisions with an individual scope, not to normative acts ${ }^{52}$. The Court, however, referred to article 37(16) of Directive 2009/72, providing that decisions taken by regulatory authorities shall be fully reasoned and justified to allow for judicial review. ${ }^{53}$ This article does not limit the duty to give reasons to acts with an individual scope (the same is true for the duty to give reasons as a general principle of good administration in EU law ${ }^{54}$ ). Hence, the NRA has to give reasons for its normative acts as well, whereas most other Belgian administrative authorities are not obliged to do so.

\subsection{Legal accountability}

Another important form of accountability takes place in the courts. There is a remarkable variety in the way that the EU legislative frameworks on network regulation phrase the guarantees that Member States have to offer in this regard. In the field of railway transport ${ }^{55}$, for instance, the legislation uses the term 'judicial review', whereas the legislation in the fields of energy ${ }^{56}$, electronic communications ${ }^{57}$ and postal services ${ }^{58}$ speak of an appeal to a 'body which is independent of the parties involved'. In the field of energy, the directives clarify that this body also has to be independent of any government. The Framework Directive for electronic communication clarifies that the appeal body 'may be a court'; if it is not judicial in nature, the directive submits it to a duty to give reasons and orders that it shall be subject to review by a court or a tribunal. It is unclear how these differences in formulation should be interpreted. Does the EU legislature indeed impose different standards for different NRAs and - if yes - what is the justification for this?

The directives offer little further guidance on the design of the judicial review process, especially in terms of the intensity of the review and of the remedies that the judge should be able to offer. ${ }^{59}$ The CJEU, however, has pronounced a few interesting judgments in this respect.

The Court has endorsed the legal accountability of NRAs in T-Mobile Austria, which was a case about locus standi. Article 4(1) of the Framework Directive provides that the appeal mechanism against NRA decisions at the national level must be open to any user or undertaking providing electronic communications networks and/or services who is affected by the decision that is being challenged. The referring court wanted to know whether this also included an undertaking holding rights to use radio frequencies and competing with the parties to a procedure for the authorisation of a transfer of rights to use radio frequencies. Referring to the interpretation that it gave to article 4(1) of the Framework Directive in its Tele 2 judgment ${ }^{60}$, the CJEU ruled that 'a strict interpretation of Article 4(1) of the Framework Directive to the effect that that provision confers a right of appeal only on persons to whom the decisions of the NRAs are addressed would be difficult to reconcile with the general objectives and regulatory principles resulting, for the NRAs, from Article 8 of that directive, and, in particular, with the objective of promoting competition ' 61 . Potential competitors of the addressee of a decision should consequently also have access to the court, in so far as the NRA's decision is adopted in the context of a procedure intended to safeguard competition and is likely to have an impact on their position on the market. ${ }^{62}$ The Court decided that these conditions were met in the case pending before the national judge. ${ }^{63}$

\footnotetext{
52 There is some debate on whether and to what extent decisions on tariffs are normative acts, but they are often treated as such.

${ }^{53}$ Court of Appeal of Brussels 6 February 2013, 2012/AR/205, 2012/AR/2017 conn. 2012/AR/220.

${ }^{54}$ See De Somer and Opdebeek [3], p. 111-112.

${ }^{55}$ Art. 56(2) of Directive 2012/34/EU.

${ }^{56}$ Art. 37(17) of Directive 2009/72/EC; article 41(16) of Directive 2009/73/EC.

${ }^{57}$ Art. 4 of Directive 2002/21/EC.

${ }^{58}$ Art. 22(3) Directive 97/67/EC.

${ }^{59}$ Taton [22], p. $180 \mathrm{ff}$. For NRAs responsible for the energy markets, some guidance is found in Commission Staff Working Paper 22 January 2010, Interpretative Note on Directive 2009/72/EC concerning common rules for the internal market in electricity and Directive 2009/73/EC concerning common rules for the internal market in natural gas - The Regulatory Authorities, http://ec.europa.eu/energy/gas electricity/interpretative notes/doc /implementation notes/2010 0121 the regulatory authorities.pdf, p. 19-20.

${ }^{60}$ Case C-426/05 Tele2 Telecommunication GmbH, EU:C:2008:103.

${ }^{61}$ Para 36.

62 Para 39.

${ }^{63}$ Case C-282/13 T-Mobile Austria GmbH, EU:C:2015:24.
} 
In another recent judgment, the CJEU ruled that a national court hearing an appeal against a decision of an NRA competent in the field of electronic communications must be able to annul that decision with retroactive effect, if it finds that to be necessary in order to provide effective protection for the rights of the undertaking who has brought the appeal. ${ }^{64}$ The Court referred specifically to article 4(1) of the Framework Directive, anchoring the right of appeal against NRA decisions, but indicated that this article is an expression of the principle of effective judicial protection safeguarded by article 47 of the Charter of Fundamental Rights of the European Union, pursuant to which it is for the courts of the Member States to ensure judicial protection of an individual's rights under EU law. ${ }^{65}$

Hence, the CJEU gives a broad interpretation to the right to effective judicial protection vis-à-vis decisions made by NRAs, both on the level of who has access to the courts and on the level of the remedy that the courts should be able to offer.

A recent judgment of the CJEU, Koninklijke KPN NV et al., sheds light on the intensity of the judicial scrutiny of NRAs' decisions and more precisely on the proportionality test. At the basis of the case was a decision of the Dutch ACM setting price caps for fixed and mobile call termination services. The referring court amongst other things wanted to know whether it wat allowed to assess the proportionality of the obligations laid down in this decision in the light of the objectives set out in article 8 of the Framework Directive and article 13 of the Access Directive $^{66}$. The CJEU ruled that the national judge may check whether the applicants have adduced sufficient evidence to show that the application of this model is not proportionate to the objectives set out in Article 8 of the Framework Directive and in Article 13 of Access Directive, in view, as appropriate, of the specific characteristics of the relevant market. The NRA's tariff obligations must be directed at achieving these objectives. The national court is not entitled, however, when carrying out a judicial review of a decision of the national regulatory authority, to require that authority to demonstrate that the obligation actually attains the objectives set out in Article 8 of the Framework Directive, as amended by Directive 2009/140. ${ }^{67}$ According to the Court, the adoption of regulatory obligations is based on a prospective analysis of market developments. Therefore, the proof that such measures attain the objectives set out in the Directive is 'impossible or excessively difficult to adduce'. ${ }^{68}$

It has been argued that the CJEU devises the proportionality test differently depending on the authority under review: it tends to be stricter when a national authority is involved than when an EU institution is under scrutiny. The reason is that the Court wants to foster European integration. ${ }^{69}$ Decisions made by national authorities are often challenged precisely because they limit the rights and freedoms conferred on individuals by EU law with the aim of reinforcing the internal market. NRAs, however, as the title of this article suggests, are 'agents of EU law'. Because of their independence from the national political arena, NRAs in the network industries specifically are considered as loyal partners of the EU institutions. They are less suspected than central national administrations of pursuing national interests rather than European ones. This perhaps explains why the CJEU prevents the proportionality test from being overburdening in this case.

The degree of scrutiny that the courts apply when they review NRAs' decisions nevertheless has important consequences for the effectiveness of judicial review. These decisions are technical in nature and are preceded by thorough (economic) research in order to obtain evidence for the policies pursued. Even though courts are becoming increasingly well-equipped to review regulatory processes in terms of expertise or knowledge ${ }^{70}$, time constraints or a lack of resources sometimes hamper the courts' ability to assess the substantive quality of regulations. As Ottow points out, the burden of proof that the courts place on the shoulders of market authorities may therefore be high: courts demand actual proof of NRAs that justifies their intervention. ${ }^{71}$ In its Koninklijke $K P N$ judgment, however, the CJEU mitigates the burden of proof that can be imposed on NRAS. In this case the question revolved around more than tasking the NRA to proof that the facts underlying its decision had been properly established and backed up by economic evidence. The national court went one step further still and asked the NRA to proof that its policy would be effective, i.e. would lead to a certain outcome.

\footnotetext{
${ }^{64}$ Case C-231/15 Prezes Urzędu Komunikacji Elektronicznej and Petrotel sp. z o.o. w Płocku, EU:C:2016:769.

${ }^{65}$ Para 20 with reference to Case C-282/13 T-Mobile Austria GmbH, EU:C:2015:24, para 33.

${ }^{66}$ Directive 2002/19/EC of the European Parliament and of the Council of 7 March 2002 on access to, and interconnection of, electronic communications networks and associated facilities (OJ 2002 L 108, p. 7).

${ }^{67}$ Case C-28/15 Koninklijke KPN NV et.al., EU:C:2016:692.

${ }^{68}$ Para 59.

${ }^{69}$ Haguenau-Moizard and Sanchez [5], p. 157.

${ }^{70}$ Mak [14], p. 301-319.

${ }^{71}$ Ottow [16], p. 18.
} 
Judicial proportionality review involves an adequacy or suitability test. The dilemma that courts face with regard to the standard of review of NRAs' decisions is often presented as being twofold: either they defer to regulators' decisions and expertise or they 'engage in fresh examinations of the merits of decisions' ${ }^{72}$ In reality, of course, there are various 'in-betweens': some courts have, for instance, adopted a procedural approach to the proportionality review. This may also imply that the regulatory body is asked to provide evidence, but this then mostly relates to the design and execution of the decision-making process. ${ }^{73}$ The preliminary question formulated by the Dutch national judge in Koninklijke KPN, however, suggests that NRAs could also be asked to provide evidence for the substantive rationality of their decisions. In this way, they actively contribute to the proportionality test by substantiating the suitability of their policies. In its judgment, the CJEU confirms that the national courts can assess whether the NRA's decisions are proportionate in the light of the objectives of EU legislation, but cannot ask the NRA to demonstrate that the obligation actually attains the objectives. This judgment should most likely be interpreted in such a way that courts cannot expect NRAs to provide conclusive evidence that their decisions will fulfil these objectives. However, it should be possible for courts to ask regulators to actively demonstrate the probability of their policies effectively contributing to the objectives that they are legally bound to pursue.

This point deserves to be pressed precisely because the broad discretionary powers that NRAs in the network industries enjoy seem to have only one substantive limit: they are justified by and can therefore only be used to achieve the goals that the EU legislature has defined in the relevant regulatory framework. If the national courts cannot assess whether their decisions indeed contribute to those goals, the prohibition of arbitrary rulemaking is hollowed. It seems reasonable and fair, considering the duty to give reasons that rests on NRAs as part of their procedural accountability, to impose a duty of cooperation on them with the aim of assisting the court in carrying out the proportionality test. ${ }^{74}$ In its Arcor judgment (2008), the CJEU ruled that, considering the lack of any rules laid down in EU law, it is up to the Member States to establish, in accordance with their rules of procedure, the rules of evidence applicable, including the allocation of the burden of proof between the NRA that made a decision and the party challenging that decision. This competence, of course, has to be exercised in accordance with the Community principles of effectiveness and equivalence of judicial protection. ${ }^{75}$

\subsection{Network accountability and the supervisory powers of the European Commission}

The various directives contain provisions that oblige NRAs in different Member States to cooperate with each other in various ways. ${ }^{76}$ The so called 'network agencies' at the EU level, such as ACER (Agency for the Cooperation of Energy Regulators) and BEREC (Body of European Regulators for Electronic Communications) play an important role in this regard. At present, the tasks of these agencies are mostly about coordinating, monitoring and advising on the work of NRAs. It has moreover been argued that these networks function as fora for accountability, since peers in networks watch each other and raise the need for self-justification in the light of self-preservation. ${ }^{77}$ In the future, though, they may be moving beyond that role. The European Commission has plans, for instance, to give ACER decision-making powers for cross-border issues that require a coordinated regional decision. ${ }^{78}$

In some cases, the European Commission itself possesses powers of oversight vis-à-vis NRA decisions in the form of binding vetoes against NRA drafts. These powers are rare ${ }^{79}$, but remarkable from a constitutional viewpoint. They give the central European executive power to directly intervene in a decision issued by a national administrative authority.

\section{Conclusion: NRAs in 'no man's land'?}

\footnotetext{
${ }_{72}$ Baldwin, Cave and Lodge [2], p. 345.

${ }^{73}$ See e.g. Rawlings [21], p. 281, 291-292 and 304.

${ }^{74}$ See e.g. an example from Belgium: Court of Appeal of Brussels 6 February 2013, 2012/AR/205, 2012/AR/2017 conn. 2012/AR/220. The Court ascertained that the Belgian federal energy regulator had neither in the decision itself (as a part of a statement of reasons), nor in its written proceedings before the court, demonstrated that the decision under scrutiny (a tariff decision) complied with the general objective anchored in article 36(d) of Directive 2009/72 ('helping to achieve, in the most cost-effective way, the development of secure, reliable and efficient non-discriminatory systems that are consumer oriented'). Hence, the relevant provisions in the decision were found to be unlawful. ${ }^{75}$ Case C-55/06 Arcor AG \& Co. KG, EU:C:2008:244, paras 188-191.

${ }^{76}$ E.g. art. 22(2) of Directive 97/67/EC; art. 7(2) of Directive 2002/21/EC; art. 37(1)(c) of Directive 2009/72/EC; art. 41(1)(c) of Directive 2009/73/EC; art. 57 of Directive 2012/34/EU.

${ }_{77}^{7}$ E.g. Maggetti [13]; Papadopoulos [18], p. 477.

${ }^{78}$ Proposal for a Regulation of the European Parliament and of the Council on the internal market for electricity (COM/2016/0379), p. 6-7.

${ }^{79}$ See art. 7(4)-(5) Directive 2002/21/EC; art. 39(5)-(6) of Directive 2009/72/EC; art. 43(5)-(6) of Directive 2009/73/EC.
} 
The Oxford English dictionary gives several definitions for the word 'agent'. At least two of these seem applicable to NRAs. The first is: 'one who exerts power'. This article demonstrated that NRAs hold several powers of various natures. In the network industries especially, NRAs' functional independence implies that they (should) exercise these powers autonomously, without any direct possibilities of oversight by national political principals. The second definition is: 'a person acting on behalf of another'. NRAs in the network industries are often seen as a special kind of independent 'agencies'. But if they are 'agents' or 'agencies', who is their 'principal'? On whose 'behalf' do they act? This is a complex question without a simple answer. NRAs lack a single principal to whom they answer or who possesses certain powers of intervention vis-à-vis their actions. They are, as this title suggests, agents of EU law, which they are supposed to implement and enforce faithfully. They answer to several fora of accountability (the European Commission, national parliaments, stakeholders, the courts, other NRAs with whom they form networks etc.), none of these exercising complete control over their actions.

This contribution paid special attention to the judicial review of NRAs' decisions. Even though accountability to the courts cannot fill the political legitimacy gap that these bodies suffer from ${ }^{80}$, it is important that judicial review of NRAs' decisions is effective. This article discussed some interesting case law of the CJEU in this respect. NRAs may find themselves in no man's land on the politico-institutional map; they are on the national courts' radar. These national courts increasingly turn to the CJEU to explore the conditions and the boundaries of the scrutiny that they can exercise and the remedies that they can offer.

\section{References}

1. Aelen, M.: Beginselen van goed markttoezicht. Boom Juridische Uitgevers, Den Haag (2014)

2. Baldwin, R., Cave, M. and Lodge, M.: Understanding Regulation. Theory, Strategy and Practice. Oxford University Press, Oxford (2012)

3. De Somer, S. and Opdebeek, I: The Duty to Give Reasons in the European Legal Area: a Mechanism for Transparent and Accountable Administrative Decision-Making? A Comparison of Belgian, Dutch, French and EU Administrative Law. Public Administration Yearbook, 97-148 (2016)

4. De Somer, S.: Autonomous Public Bodies and the Law. A European Perspective. Edward Elgar, Cheltenham (2017)

5. Haguenau-Moizard, C. and Sanchez, Y.: The principle of proportionality in European law. In: Ranchordás, S. and de Waard, B. (eds.) The Judge and the Proportionate Use of Discretion. A comparative study. Routledge, New York (2016)

6. Halberstam, D.: The promise of comparative administrative law: a constitutional perspective on independent agencies. In: RoseAckerman, S. and Lindseth, P.(eds.) Comparative Administrative Law. Edward Elgar, Cheltenham (2010)

7. Harlow, C. and Rawlings, R.: Law and Administration. Cambridge University Press, Cambridge (2009)

8. Hofmann, H.C.H. and Mihaescu, B.C.: The Relation between the Charter's Fundamental Rights and the Unwritten General Principles of EU Law: Good Administration as the Test Case. European Constitutional Law Review 73-101 (2013).

9. Kańska, K.: Towards Administrative Human Rights in the EU. Impact of the Charter of Fundamental Rights. European Law Journal, 296-326 (2004).

10. Kristjánsdóttir, M.V.: Good Administration as a Fundamental Right. Icelandic Review of Politics and Administration 237-255 (2013).

11. Lavrijssen, S. and Ottow, A.: Independent Supervisory Authorities: A Fragile Concept. Legal Issues of Economic Integration, 419446 (2012)

12. Lavrijssen, S. and Ottow, A.: The Legality of Independent Regulatory Authorities. In: Besselink, L., Pennings, F. and Prechal, S. (eds) The eclipse of the legality principle in the European Union. Kluwer, Alpen aan den Rijn (2011)

13. Maggetti, M.: Legitimacy and Accountability of Independent Regulatory Agencies: A Critical Review. Living Reviews in Democracy (2010).

14. Mak, E., Judicial review of regulatory instruments: the least imperfect alternative? Legisprudence: international journal for the study of legislation, 301-319 (2012)

15. Nicolaïdes, P.: Regulation of Liberalised Markets: A New Role for the State. In: Geradin, D., Muñoz, R. and Petit N. (eds.) Regulation trough Agencies in the EU. A New Paradigm of European Governance. Edward Elgar, Cheltenham (2005)

16. Ottow, A.: Market \& Competition Authorities. Good Agency Principles. Oxford University Press, Oxford (2015)

${ }^{80}$ De Somer [4], p. 270 ff. 
17. Ottow, A.: The Different Levels of Protection of National Supervisors' Independence in the European Landscape. In: Comptois, S. and de Graaf, K. (eds.) On judicial and quasi-judicial independence. Boom Juridische Uitgevers, Den Haag (2013)

18. Papadopoulos, Y.: Problems of Democratic Accountability in Network and Multilevel Governance. European Law Journal, 469486 (2007).

19. Petit, N.: The Proliferation of National Regulatory Authorities alongside Competition Authorities: A Source of Jurisdictional Confusion. GCLC Working Paper 02/04. Available at https://www.coleurope.eu/research-paper/proliferation-nationalregulatory-authorities-alongside-competition-authorities.

20. Prosser, T.: Regulation and Legitimacy. In: Jowell, J. and Oliver, D. (eds.) The Changing Constitution, $7^{\text {th }}$ edn. Oxford University Press, Oxford (2011)

21. Rawlings, R.: Changed Conditions, Old Truths: Judicial Review in a Regulatory Laboratory. In: Oliver, D., Prosser, T. and Rawlings, R. (eds.) The Regulatory State. Constitutional Implications. Oxford University Press, Oxford, 2010.

22. Taton, X.: Les recours juridictionnels en matière de régulation. Larcier, Brussels (2010)

23. Van den bergh, C.: The Relationship between Sector Specific Regulation and Competition Law in the Energy Sector - Living Apart Together? In: Delvaux, B., Hunt, M. and Talus, K. (eds.) EU Energy Law and Policy Issues. Intersentia, Cambridge (2012)

24. Vegter, J.G. and Maandag, P.I.W.R.: Regelgeving en beleid door onafhankelijke toezichthouders: de praktijk van ACM. RegelMaat, 201-220 (2015).

25. Ziller, J.: Les autorités administratives indépendantes entre droit interne et droit de l'Union européenne. Revue Française de Droit Administratif, 901-906 (2010) 